\title{
De onderwijsvisitatie geneeskunde 2003
}

\author{
H.J. Huisjes, J. Denekens
}

\section{Samenvatting}

Inleiding: In dit artikel worden de bevindingen opgedaan bij de onderwijsvisitatie 20032004 door twee commissieleden enerzijds samengevat, anderzijds van persoonlijk commentaar voorzien.

Resultaten: Er zit veel beweging in het medisch onderwijs, in het bijzonder als het gaat om de didactische werkvormen. Kwaliteitsverschillen worden kleiner, maar een kritische bezinning op werkelijke vernieuwing blijft nodig. De academische vorming krijgt meer aandacht dan vroeger. Voor zover die betrekking heeft op de wetenschappelijke vorming mag nog wel eens worden nagedacht over doelmatigheid en doeltreffendheid. Ook aan de toetsing als instrument om de competentie te beoordelen moet meer aandacht worden besteed. De opleidingsrendementen zijn laag. Er is geen fungerend systeem om de kwaliteit van de afgestudeerden te beoordelen. De organisatorische ontwikkeling in de richting van opleidingsinstituten leidt tot een professionele benadering en meer integratie. Het belang van de disciplines en de betekenis van de docent mag daarbij niet uit het oog verloren worden. De invloed van de onderwijstaak op het personeelsbeleid van de opleidingen komt aarzelend op gang. Het internationaliseringsbeleid kan nog verder worden uitgewerkt. De massaliteit die het gevolg is van de verhoging van de numerus fixus is een risico voor de kwaliteit.

Conclusie: Er zit een consequente lijn in de sturing van het medisch onderwijs in de afgelopen decennia via raamplannen en visitatierapporten. Het niveau van het onderwijs is zonder meer aanvaardbaar te noemen. (Huisjes HJ, Denekens J. De onderwijsvisitatie geneeskunde 2003. Tijdschrift voor Medisch Onderwijs 2004;23(3):127-132.)

\section{Inleiding}

Het verslag van de derde onderwijsvisitatie geneeskunde werd op 10 juni 2004 aan de VSNU aangeboden. De vorige visitaties werden gehouden in 1992 en 1997. In tegenstelling tot de vorige keer werden er nu drie commissies gevormd, die respectievelijk de opleidingen geneeskunde, gezondheidswetenschappen en die in de overige gerelateerde wetenschappen moesten beoordelen. De hier besproken visitatie heeft alleen betrekking op de acht opleidingen geneeskunde in Nederland.

Men kan zich kritisch afvragen wat precies het gezag is van de uitspraken van een commissie van acht mensen plus een ambtelijk secretaris over de kwaliteit van het medisch onderwijs. Dat oordeel kon over het algemeen niet gebaseerd zijn op exacte metingen, maar kwam vooral tot stand op basis van rapportages (de zogenaamde zelfstudies) en andere documenten, beschikbaar gesteld door de opleidingen, en gesprekken met een groot aantal personen uit de opleidingen. De spreiding van disciplines en de ervaring van de commissieleden, de intensieve gedachtewisseling in de commissie alsmede de ruime mogelijkheden voor de opleidingen om te reageren op de conceptrapportage hebben waarschijnlijk grove misslagen voorkomen. Het lijkt aannemelijk dat het belang- 
rijkste doel van de visitatie, de opleidingen een niet al te zeer vertekenende spiegel voor te houden, is bereikt. Vergelijkende scores, zoals opgenomen in bijlage 3 van het visitatierapport, zijn niet zo exact als ze op het eerste gezicht lijken en voegen weinig toe aan het beeld dat in het algemene deel wordt geschetst: de cijfers zijn gegeven binnen een vierpuntsschaal, hebben geen lineair karakter en laten dus geen rekenkundige bewerking toe.

\section{Resultaten}

De overheersende indruk is er één van beweging en activiteit, overigens niet noodzakelijkerwijs hetzelfde als werkelijke vernieuwing. Alle opleidingen denken na over hun programma en de meeste hebben hun curriculum niet lang geleden ingrijpend veranderd of zijn daar mee bezig. Ten dele wordt dit door de omstandigheden gedicteerd: het zal moeilijk zijn de kwaliteit te handhaven bij de grote aantallen studenten die de komende jaren moeten worden geaccommodeerd. Maar er is ook werkelijke belangstelling, te oordelen naar de bewonderenswaardige wijze waarop sommige van de opleidingen die zes jaar geleden nog forse kritiek van de visitatiecommissie moesten incasseren, een heel nieuw programma hebben opgebouwd. Zijn die beweging en activiteit dan het gevolg van het visitatiesysteem? Ten dele zeker. Lang niet alle aanbevelingen van de vorige visitatiecommissie zijn door de opleidingen opgevolgd. Maar als periodiek een formeel openbaar oordeel wordt geveld over één van de hoofdtaken van de universiteit (nog afgezien van de beoordeling via informele openbare cijferlijsten), dan is deftig afstand nemen van dat externe oordeel niet goed vol te houden. Maar dat geldt alleen als de betrokken hoofdtaak er ook werkelijk toe doet. En dat is in toenemende, zij het nog niet in voldoende, mate het geval. Medisch onderwijs staat mondiaal in de belangstelling van onderwijs- en inhoudsdeskundigen en Nederland loopt daarbij zeker niet achter. Zo lang de veranderingen wezenlijke zaken betreffen, kan dit tot voldoening strekken.

Het visitatieprotocol bevat een dertiental aspecten waaraan de commissie expliciet aandacht had te schenken. Enkele punten uit die lijst zullen hier worden besproken.

\section{Didactische werkvormen}

Kenmerkend voor de nieuwe curricula zijn een neiging tot integratie van de basisvakken en een combinatie van grooten kleinschalig onderwijs. Ook het samenspel van blok- en lijnonderwijs lijkt zich door te zetten, ook al ontbreekt het nog wel eens aan de juiste onderwijskundige methodologie. De voordelen hoeven hier niet nader te worden uiteengezet. Toch verdienen ook de nadelen aandacht. Eén daarvan willen we noemen. De disciplines zijn voor de student minder goed herkenbaar. Niet zelden staat hetzij de leerlijn (bijvoorbeeld ethiek) te los van de andere onderwijsonderdelen, zodat het verband verloren gaat, ofwel ze is zo versmolten met de andere onderdelen dat ze voor de student niet meer zichtbaar is. Er moet een nieuw evenwicht worden gevonden tussen disciplinegeoriënteerd en geïntegreerd onderwijs.

\section{Eigen identiteit opleidingen}

Interessant is dat enkele opleidingen hun afgestudeerden een karakteristiek profiel willen meegeven. Die ontwikkeling is in lijn met de behoefte aan decentrale selectie. Bovendien kan de identificatie van de docenten met de opleiding er door bevorderd worden. Toch wil noch het één, noch het ander vooralsnog erg lukken: de com- 
missie heeft (nog) geen herkenbaar geprofileerde artsen aangetroffen en de meeste opleidingen hebben niet gekozen voor decentrale selectie.

\section{Academische vorming}

Evenals de andere academische opleidingen leidt de geneeskundestudie op voor een beroep. Sommigen leiden daaruit af dat de opleiding tot arts een beroepsopleiding is, wat dat ook moge betekenen. Toegegeven moet worden dat de typisch academische kenmerken van de artsopleiding in de afgelopen decennia niet op de voorgrond hebben gestaan. Te denken valt aan reflectie (bijvoorbeeld op de eigen verantwoordelijkheid en op de ethische kant van het medisch handelen) en aan wetenschappelijke vorming. Daarin begint zich een verandering af te tekenen. Ethiek is een onderdeel van de curricula in alle opleidingen, 'diversiteit' (de betekenis van culturele achtergrond en sekse) van zowel patiënten als studenten is geen vreemd woord meer, reflectie begint een sleutelwoord te worden en de wetenschappelijke vorming gaat verder dan een cursus medische statistiek. Hoewel nog niet gezegd kan worden dat er aan de uitvoering niets mankeert, zijn dit toch belangrijke ontwikkelingen.

\section{Wetenschappelijke vorming}

Voor wat betreft de wetenschappelijke vorming valt op dat hier en daar trajecten zijn gestart voor wetenschappelijk geïnteresseerde, bovenmodale studenten. Hierbij zijn twee kanttekeningen te maken. Ten eerste, het bedienen van de happy few kan geen alibi zijn voor het verwaarlozen van de aurea mediocritas. Het is te hopen dat de ervaringen opgedaan in de 'master classes' ten goede komen aan de wetenschappelijke vorming van alle studenten. En ten tweede: de algemeen geldende op- vatting is dat alleen het zelf bedrijven van het wetenschappelijk handwerk de wetenschappelijke attitude kan bijbrengen. Dat moge zo zijn, maar het is niet voldoende. Is het niet minstens zo belangrijk dat de student leert wetenschappelijk te denken ook over wetenschap?

Een interessante anekdote: begeleiders van studenten in de wetenschappelijke stage neigen tot een overmatig positieve beoordeling van het werk van hun pupillen. Zo kon het voorkomen dat een kwart van een aselecte steekproef van stageverslagen aan de top tien procent werd toegewezen. Iets voor nader onderzoek?

\section{Toetsing}

De toetsing blijft een probleem. Alle opleidingen zien het belang in van de toetsing als belangrijkste bepalende factor voor het leerproces. Dat wil nog niet zeggen dat ze er volgens de commissie alle in geslaagd zijn "een samenhangend en gevarieerd toetsprogramma [tot stand te brengen] tot en met de klinische fase waarbij longitudinaal wordt getoetst, zowel aan de formatieve als aan de summatieve functie van de toetsing recht wordt gedaan en het dekken van de eindtermen (Raamplan) goed wordt bewaakt." Wel begint de acceptatie van de voortgangstoets (een kennistoets waarbij de eisen niet afhankelijk zijn van het onderwijsproces) toe te nemen: de helft van de opleidingen maakt er gebruik van, maar de interpretatie van de verschillen varieert. In verschillende opleidingen is de invloed van de examencommissie niet in overeenstemming met haar belangrijke status. Wellicht ligt hier een aanknopingspunt voor het verbeteren van de toetsing, bijvoorbeeld in de richting van competentiebeoordeling. 


\section{Studielast}

De studiebelasting overschrijdt nergens de grenzen die in Nederland acceptabel worden geacht; dat vinden zelfs de studenten. Erg verbazingwekkend is dat niet, want een gemiddelde van 30 uren per week laat in ruime mate tijd over voor andere zaken. Des te merkwaardiger is daarom het lage niveau van de rendementen. In het jaar 2000-2001 haalde gemiddeld $63 \%$ van de studenten de propedeuse binnen een jaar (variatie 35-82\%). Nog geen $7 \%(0-22 \%)$ van het cohort $1995-$ 1996 werd arts binnen de nominale periode van zes jaar. Hoewel dergelijke cijfers niet nieuw en algemeen geaccepteerd zijn, zouden ze toch stof tot nadenken moeten vormen. Moet de prestatie van de opleidingen als onder de maat worden beschouwd? Schiet de vooropleiding tekort? Zijn de studenten lui? Het opvoeren van de rendementen en de daarmee gepaard gaande verhoging van de uitstroom zou een deel van de sterke stijging van de numerus fixus kunnen vervangen.

\section{Kwaliteit afgestudeerden}

Een van de parameters die de commissie ter beoordeling voorgelegd kreeg, was de kwaliteit van de afgestudeerden. Die vraag was eigenlijk niet te beantwoorden, omdat er geen metingen beschikbaar zijn (de voortgangstoetsen geven uiteraard geen uitsluitsel over de competentie). Hoewel onderzoek op dit gebied notoir moeilijk is, is het onbevredigend dat de resultaten van de inspanningen van opleidingen en studenten niet beter in kaart kunnen worden gebracht.

\section{Organisatie}

Alle opleidingen op één na hebben een opleidings- (of onderwijs-)instituut opgericht en alle instituten op één na hebben een directeur. Verder zijn er nogal wat verschillen in de inrichting van de instituten, ondanks het feit dat de belangrijkste taken duidelijk zijn: onderwijs (laten) geven, ondersteunen, en evalueren en ontwerpen. De verscheidenheid komt ook tot uiting in de interne kwaliteitszorg: op dit terrein zijn er evenveel systemen als opleidingen. Misschien hangt ze samen met de rol die de instituten spelen in de vernieuwing van het onderwijs. Ze vormen als het ware de neerslag van het denken van de leiding van de opleidingen over de bevoegdheden en verantwoordelijkheden op het gebied van het onderwijs. Hoewel niet alle instituten dezelfde kwaliteit leveren, lijkt het er in het algemeen op dat het onderwijs veel professioneler wordt benaderd dan zeg twintig jaar geleden. De nadruk is verlegd van de belangenstructuur met wettelijk voorgeschreven commissies (waarin iedere geleding aan het woord moest kunnen komen) naar het deskundigen-instituut, waarin professionaliteit en doeltreffendheid de plaats van de belangen hebben overgenomen. De verschillen per opleiding laten zien dat dit proces nog lang niet voltooid is. Een nadeel is zoals altijd in dit soort organisaties de kans op ongebreidelde groei en bureaucratisering. Een valkuil zou ook kunnen zijn dat de instituten met een beperkte doelstelling te werk gaan en dat de 'echte' opleiders uit het zicht verdwijnen en ook niet meer in hun capaciteit worden aangesproken. Zo is empathie maar beperkt programmeerbaar; ze moet vooral opgenomen zijn in de houding van de docent.

In het personeelsbeleid wordt het belang dat gehecht wordt aan de onderwijstaak aarzelend weerspiegeld: onderwijsleerstoelen en onderwijs-UHD-posities zijn in de meeste opleidingen geen anathema meer. Onderwijstrainingen zijn over het algemeen in ruime mate aanwezig en worden soms zelfs verplicht gesteld. Wel is het 
deel van de werktijd dat de staf aan onderwijs geacht wordt te besteden nog steeds klein, 10 tot $20 \%$. Een voorzichtige en tamelijk grove schatting van het aantal fte's beschikbaar voor onderwijs komt uit op omstreeks 100 per opleiding.

\section{Internationalisering}

Het internationaliseringbeleid (inkomende en uitgaande mobiliteit van studenten en docenten) staat niet overal in het centrum van de belangstelling. Veel opleidingen kennen geen goed omschreven doelstellingen. De aantallen inkomende buitenlandse studenten zijn veel kleiner dan de aantallen Nederlanders die voor een stage vertrekken, zeker als migranten niet worden meegeteld. Hier en daar is een begin gemaakt met Engelstalig onderwijs en 'summer courses' zijn geen uitzondering.

\section{Conclusie}

$\mathrm{Al}$ met al ziet het medisch onderwijs in $\mathrm{Ne}$ derland er gezond uit. Er is veel activiteit en dat kan beschouwd worden als een teken van leven. Niet alles gaat even goed. Er zijn kwaliteitsverschillen, maar die zijn niet groter dan in de gegeven situatie verwacht mag worden. Als er echte probleemgebieden aan te wijzen zijn, dan moet in de eerste plaats gedacht worden aan de massaliteit door de ophoging van de numerus fixus. Aan de toetsing zou meer aandacht moeten worden besteed, in het bijzonder in de klinische fase van de opleiding. De opbouw van de academische vorming moet met kracht worden doorgezet. Een vraag die nauwelijks aan de orde komt, is die naar de relatie tussen het medisch onderwijs en wat er maatschappelijk nodig is om goede kwaliteit van zorg te leveren.

De benaderingswijze van het Disciplineoverlegorgaan Medische Wetenschappen, op instigatie van de overheid, uit het eind van de jaren tachtig en het begin van de jaren negentig, die de eindtermen van de opleiding bindend maakte voor alle opleidingen, maar de wijze waarlangs die doelen werden bereikt aan de (toen nog) faculteiten overliet, is doeltreffend geweest. Twee raamplannen en drie visitaties verder lijkt die conclusie wel getrokken te kunnen worden. Het Raamplan bepaalt de bindende eindtermen en de opleidingen streven er naar die te realiseren. De wegen waarlangs dat gebeurt lopen sterk uiteen.

Niet lang geleden werd de Onderwijscommissie DMW (DMW-OCG) opgericht, waarin de opleidingsdirecteuren overleggen. Is dat een aanwijzing dat niet alleen de eindtermen, maar ook de weg daar naar toe onderwerp van discussie aan het worden zijn tussen de opleidingen? Dat zou het wegnemen van tekortkomingen zeer ten goede komen.

\section{Dankbetuiging}

Dit artikel had uiteraard niet geschreven kunnen worden zonder de intensieve betrokkenheid van alle commissieleden en de secretaris bij de visitatie. Dat waren: dr. S.M. Bolhuis, prof. dr. H.J. Jongsma, prof. dr. J. van der Meer, drs. G.B.S. Penders, prof. dr. F. Sturmans, prof. dr. M.A. Verkerk, alsmede drs. S. Looijenga. Voor zover in dit stuk standpunten naar voren komen die afwijken van die van de commissie als geheel, zijn deze voor rekening van de auteurs.

\section{De auteurs:}

Prof. dr. H.J. Huisjes is emeritus hoogleraar en oud-decaan van de Faculteit der Medische Wetenschappen, Rijksuniversiteit Groningen. Hij trad tevens op als voorzitter van de Visitatiecommissie Geneeskunde.

Prof. dr. J. Denekens is hoogleraar Huisartsgeneeskunde en vice-rector voor onderwijszaken aan de Universiteit Antwerpen. Zij was tevens lid van de Visitatiecommissie Geneeskunde.

\section{Correspondentieadres:}

Prof. dr. H.J. Huisjes, Kalkwijk 177, 9603 TC Hoogezand,hprocul@cs.com. 


\section{Summary}

Introduction: This article is a summary of the findings from the site visits in 2003 and 2004 by the Review Committee that assessed the quality of medical education at the eight Medical Schools in the Netherlands. The authors of this article are members of the committee. Where this article reflects their personal opinions, these are not necessarily those of the committee.

Results: There is a lot going on in medical education, especially with regard to didactic methods. Differences in quality are diminishing, but critical reflection on true innovation remains necessary. The interest in academic 'Bildung' is increasing. The effectiveness and efficiency of scientific training should receive more attention, as does testing as an instrument for competence assessment. Output in terms of graduation rates and time to completion should be improved. Currently, there is no adequate system in place to measure the quality of the output of medical education. The development of Education Institutes within the Medical Schools furthers a professional approach and integrated teaching. This should not deflect attention from the importance of disciplines and the personal input of teachers. The influence of the teaching tasks on personnel management is slowly getting underway. Ideas on international exchange programmes and their implementation should be worked out. The increasing numbers of students that are being admitted to Medical Schools constitute a threat to the quality of medical education.

Conclusion: The policies on medical education in the Netherlands have been consistent over the past decades. The quality of teaching is adequate. (Huisjes HJ, Denekens J. Medical education in the Netherlands, the results of the national review of medical education. Dutch Journal of Medical Education 2004;23(3):127-132.) 